\title{
Depredating sperm whales in the Gulf of Alaska: local habitat use and long distance movements across putative population boundaries
}

\author{
J. M. Straley ${ }^{1, *}$, G. S. Schorr ${ }^{2}$, A. M. Thode $^{3}$, J. Calambokidis ${ }^{2}$, C. R. Lunsford ${ }^{4}$, \\ E. M. Chenoweth ${ }^{1}$, V. M. O'Connell ${ }^{5}$, R. D. Andrews ${ }^{6}$ \\ ${ }^{1}$ University of Alaska Southeast, Sitka, Alaska 99835, USA \\ ${ }^{2}$ Cascadia Research Collective, Olympia, Washington 98501, USA \\ ${ }^{3}$ Scripps Institution of Oceanography, La Jolla, California 92037, USA \\ ${ }^{4}$ Ted Stevens Marine Research Institute, NOAA Fisheries, Juneau, Alaska 99801, USA \\ ${ }^{5}$ Alaska Longline Fishermen's Association, Sitka, Alaska 99835, USA \\ ${ }^{6}$ School of Fisheries and Ocean Sciences, University of Alaska Fairbanks and the Alaska SeaLife Center, Seward, Alaska 99664, USA
}

\begin{abstract}
Satellite tags were attached to 10 sperm whales Physeter macrocephalus (1 whale was tagged in 2 different years) to determine the movements of sperm whales involved in removal of sablefish from longline fishing gear in the Gulf of Alaska (GOA). Tags transmitted from 3 to $34 \mathrm{~d}$ $($ median $=22)$ in 2007 and 7 to $158 \mathrm{~d}$ (median $=45)$ in 2009. Seven whales stayed in the GOA; all were associating with fishing vessels along the slope. Two whales headed south in June shortly after being tagged; one reached the inner third of the Sea of Cortez; the other's last location was offshore Mexico at $14^{\circ} \mathrm{N}$. A third whale stayed in the GOA until October and then headed south, reaching central Baja, Mexico, $158 \mathrm{~d}$ after tagging. The whales that travelled to lower latitudes followed no pattern in timing of departure, and at least 2 had different destinations. All whales passed through the California Current without stopping and did not travel to Hawaii; both are areas with known concentrations of sperm whales. Whales travelled faster when south of $56^{\circ} \mathrm{N}$ than when foraging in the GOA (median rate of median horizontal movement $=5.4$ [range: 4.1 to 5.5] and 1.3 [range: 0.6 to 2.5 ] $\mathrm{km} \mathrm{h}^{-1}$, respectively). Tagged sperm whales primarily travelled over the slope, but one spent considerable time over the ocean basin. Information on the timing and movement patterns of sperm whales may provide a means for fishermen to avoid fishing at whale hot spots, potentially reducing interactions between whales and fishermen.
\end{abstract}

KEY WORDS: Sperm whales $\cdot$ Satellite tags $\cdot$ Shelf $\cdot$ Slope $\cdot$ Ocean basin $\cdot$ Rate of horizontal movement $\cdot$ Demersal longlines $\cdot$ Depredation

\section{INTRODUCTION}

Sperm whales Physeter macrocephalus associate with fishing operations, particularly longline operations, in a number of locations around the globe (Rice 1989, Ashford et al. 1996, Capdeville 1997, Nolan \& Liddle 2000). In the Gulf of Alaska (GOA) depredation by sperm whales of longline gear set for sablefish has been occurring for over 3 decades. In 1995 a change in management resulted in an expanded fishing season. This change allowed increased opportunities for sperm whales to depredate longline fishing gear, and by 1997 reports of depredation had increased substantially (Hill et al. 1999, Sigler et al. 2007).

Sperm whales feed primarily on various species of cephalopods (Okutani \& Nemoto 1964, Berzin \& Yablokov 1971, Gaskin 1982, Rice 1989, Santos et al. 
1999), but there are regions where fish is the predominant component of their diet (Berzin \& Yablokov 1971, Clarke \& Macleod 1976, Kawakami 1980, Gosho et al. 1984, Rice 1989). Kawakami (1980) reviewed sperm whale diets worldwide and found that fish were an important part of their diet in the northern and northeastern parts of the North Pacific, off New Zealand, and in the northern part of the North Atlantic. Stomach samples from specimens examined at whaling stations from whales caught in Alaska revealed that cephalopods were an important food in the western Aleutians and Bering Sea, but that fish became progressively more important towards the eastern Aleutians and into the GOA (Okutani \& Nemoto 1964).

Sperm whales are widely distributed across the entire North Pacific. They were subjected to 2 waves of commercial whaling and were heavily exploited in the North Pacific until the late 1970s (Ivashchenko et al. 2011, 2013, Mizroch \& Rice 2013). Although sperm whale catches in the GOA overall were lower than other areas of the North Pacific, in one year, 1964, over 1800 sperm whales were removed from the GOA alone, north of $50^{\circ} \mathrm{N}$ (N. V. Doroshenko et al. unpubl. data, Ivashchenko pers. comm.). No sperm whales were removed in this area by the Soviet catcher fleet after 1967. Although sperm whale numbers have likely increased and possibly recovered since the cessation of commercial whaling, they continue to be listed as an endangered species in US waters (Allen \& Angliss 2013).

Some data exist on sperm whale year-round presence in the GOA, from acoustic recordings from bottom-mounted recorders (Mellinger et al. 2004). However, these data could not be used to determine whether the same sperm whales were present year round, representing a stable population, or whether vocalizations were from multiple transitory whales passing through the area.

Population structure is poorly understood and has been the subject of debate for decades (Whitehead 2003). Low genetic diversity worldwide provided little basis for differentiating groups of whales using mtDNA or nuclear markers (Lyrholm et al. 1999). Whitehead (2003) and Rendell et al. (2012) have proposed a population structure based upon groups of whales using the same communication or vocal dialect unbound from geography and genetics. Thus, a species with low genetic diversity and wide ranging movements, perhaps including males foraging in ocean basins apart from the females and immature whales, is culturally connected acoustically rather than geographically.
Mesnick et al. (2011) revisited the population structure for sperm whales in the North Pacific using single-nucleotide polymorphisms (SNPS) along with microsatellite genotyping and mitochondrial DNA methods. Currently, in US waters, 3 populations are recognized: (1) California Current, (2) Hawaii, and (3) Alaska. According to Mesnick et al. (2011), sperm whales present in the California Current are differentiated genetically, whereas sperm whales from the Hawaiian Archipelago and the eastern tropical Pacific could not be fully differentiated. Their results were clear that the high-latitude male sperm whales in Alaska originated from not one but multiple populations. While application of genetic techniques is promising, it will be challenging and perhaps impossible to define populations of sperm whales geographically (see Dufault et al. 1999). This may be particularly true for males who, when sexually and physically mature, roam widely, with reported movements of over $5000 \mathrm{~km}$ (Mizroch \& Rice 2013) and may not return to breed in the ocean where they were born (Lyrholm et al. 1999). Essentially, while some genetic distinctions exist among sperm whale populations, it is still an emerging story.

Whitehead (2003) highlighted that one of the largest gaps in our understanding of sperm whales is the movements of males. How mature males move throughout the oceans will define and influence mating strategies and gene flow. He summarized that male movement consists of gradual movement to higher latitudes with age, and at about age 27 (Best 1979), periodic, but not necessarily seasonal, transits occur between the lower latitude feeding/breeding grounds and higher latitude feeding grounds. These males have variable patterns of movement while at high latitudes and move almost continually at low latitudes, with repeat visitation to groups of females. In the eastern tropical Pacific, few adult males were seen across a 19 yr study in an area where females and immature sperm whales roam widely (Whitehead et al. 2008). Clearly, male movements are complex, with individual variability over large temporal and spatial scales.

In 2003, fishermen, scientists, and managers formed the Southeast Alaska Sperm Whale Avoidance Project (SEASWAP) to better understand sperm whale interactions with the longline fishery for sablefish in the eastern GOA (Straley et al. 2005). SEASWAP partners are working cooperatively towards a common goal of investigating and documenting the occurrence of sperm whales in association with longline fishing to develop strategies to minimize this interaction (Thode et al. 2007). Sable- 
fish occur on the continental slope, and most commercial longliners fish for sablefish in water depths between 600 and $1000 \mathrm{~m}$ (Hanselman et al. 2011). SEASWAP is focused along the continental slope of the eastern GOA and has documented sperm whales using this habitat extensively for foraging (Mathias et al. 2012).

Using photographic sampling methods, SEASWAP documented 81 individual whales and estimated that 105 (95, 125: $95 \%$ Bayesian credible interval) male sperm whales were involved in depredation of sablefish in the eastern GOA between 2003 and 2011 (SEASWAP unpubl. data). In 2006, SEASWAP began collaboration with NOAA Fisheries sablefish assessment program and placed biologists aboard federal survey vessels to document whale presence, behavior, and interactions across the entire GOA through 2011, but excluding 2008. The federal survey fishes the same stations along the slope each year; thus, sampling is consistent throughout the entire GOA. These data allowed a glimpse of how sperm whales move along the continental slope beyond the SEASWAP study area. The 2011 SEASWAP/NOAA sperm whale catalog consisted of identification photographs of the distinctive flukes of 104 individual whales from the GOA, as far west as Kodiak Island. Repeated sightings of individual whales documented that 31 sperm whales were photographed both in the eastern GOA and in at least one other area in the GOA. These data demonstrated that at least onethird, and perhaps all, of the sperm whales present in the GOA roam widely along the slope. However, the data collected just along the slope did not shed insight on whether the shallower waters on the shelf and the deeper ocean basin beyond the slope were also preferred areas for sperm whales in the GOA. Furthermore, it was not clear whether sperm whales observed within the SEASWAP study area stayed for extended periods or whether they passed through, moving beyond the GOA.

To further investigate the movements, locations, and destinations of sperm whales associating with longline vessels along the edge of the continental shelf in the GOA, we deployed satellite tags on 10 males in 2007 and 2009. Information on the timing and movement patterns of sperm whales in the GOA may provide a means for fishermen to avoid whales. Over time these longitudinal data will document the most skilled, repeat depredators and give fishermen an option to avoid fishing at known whale hot spots based upon past location data from satellite tags, thus reducing the opportunity for interactions between whales and fishermen in Alaskan waters.

\section{MATERIALS AND METHODS}

\section{Study area}

Satellite tags were deployed on sperm whales in conjunction with other SEASWAP activities along the slope 11 to $56 \mathrm{~km}$ offshore from $56^{\circ}$ to $57^{\circ} \mathrm{N}$ latitude, in the eastern GOA during July 2007 and June 2009. The SEASWAP study area is located in the eastern GOA from $56^{\circ}$ to $58^{\circ} \mathrm{N}$.
Table 1. Deployment details for 10 sperm whales Physeter macrocephalus satellite tagged 11 times off Sitka, AK, in the eastern Gulf of Alaska (GOA), 2007 and 2009. SWsat3 and SWsat7 are the same whale

\begin{tabular}{|c|c|c|c|c|}
\hline Whale & Catalog ID & $\begin{array}{c}\text { Date } \\
\text { deployed }\end{array}$ & $\begin{array}{c}\text { Date last } \\
\text { transmission }\end{array}$ & $\begin{array}{c}\text { Signal } \\
\text { contact (d) }\end{array}$ \\
\hline SWsat1 & No ID & $08 \mathrm{Jul} 2007$ & 18 Jul 2007 & 9 \\
\hline SWsat2 & GOA068 & $08 \mathrm{Jul} 2007$ & 11 Aug 2007 & 34 \\
\hline SWsat3 & GOA047 & 14 Jul 2007 & 17 Jul 2007 & 3 \\
\hline SWsat4 & GOA008 & $17 \mathrm{Jul} 2007$ & 12 Aug 2007 & 26 \\
\hline SWsat5 & GOA092 & 17 Jul 2007 & 04 Aug 2007 & 18 \\
\hline \multirow[t]{2}{*}{ SWsat6 } & GOA096 & 17 Jul 2007 & 19 Aug 2007 & 33 \\
\hline & & \multicolumn{3}{|c|}{ Median duration $2007=22($ range 31$) d$} \\
\hline SWsat7 & GOA047 & 12 Jun 2009 & 17 Nov 2009 & 158 \\
\hline SWsat8 & No ID & 13 Jun 2009 & 28 Jul 2009 & 45 \\
\hline SWsat9 & GOA018 & 14 Jun 2009 & 30 Jun 2009 & 16 \\
\hline SWsat10 & GOA104 & 14 Jun 2009 & 05 Aug 2009 & 52 \\
\hline \multirow[t]{2}{*}{ SWsat11 } & GOA114 & 21 Jun 2009 & 28 Jun 2009 & 7 \\
\hline & & \multicolumn{3}{|c|}{ Median duration $2009=45($ range 151$) \mathrm{d}$} \\
\hline
\end{tabular}

\section{Satellite tags}

Satellite-linked transmitters and the Argos satellite system were used to collect location data for 10 sperm whales in 2 different years, 2007 and 2009, with 1 whale tagged in both years (Table 1). Tags in the Low Impact Minimally Percutaneous External Transmitter (LIMPET) configuration measured $6.0 \times 3.5 \times$ $2.5 \mathrm{~cm}$, weighed approximately $50 \mathrm{~g}$ and had 2 barbed titanium darts $(0.4 \mathrm{~cm}$ in diameter, $6.5 \mathrm{~cm}$ penetration length; Andrews et al. 2008). Whales were approached from a small vessel to within a distance of 3 to $10 \mathrm{~m}$. Transmitters were deployed using a crossbow to implant the darts into the dorsal fin or body just below the dorsal fin. Tagging occurred while whales were following or closely associating with longline 
fishing vessels, with the exception of 1 individual. This whale was tagged $5 \mathrm{~km}$ distant from a fishing vessel. Within a few hours after tagging this whale travelled directly to the fishing vessel which had started hauling the catch from a demersal longline set. Tags were programmed on a duty cycle to transmit daily for $50 \mathrm{~d}$, then every third day for $1.5 \mathrm{mo}$, every fifth day for $2 \mathrm{mo}$, and then every tenth day thereafter. However, only 2 whales, SWsat7 and SWsat10, transmitted for $>50 \mathrm{~d}$.

All satellite tag position estimates were filtered using the Douglas Argos-Filter Version 7.06 (http:// alaska.usgs.gov/science/biology/spatial/douglas.html; Douglas et al. 2012). The Douglas Argos-Filter uses an algorithm to assess each Argos location and removes the improbable locations from the dataset. The first step uses distances between locations. The filter retained all Location Class 2 and 3 position estimates, classed by Argos as highly accurate, and consecutive position estimates that were separated by $3 \mathrm{~km}$ or less. This is based upon the logic that it would be unusual for consecutive erroneous locations to occur within the same small location area. The second step of the filter evaluated the bearings, vectors, velocity, and internal angles of intersection to remove implausible position estimates that are indicative of spurious movement rates or changes in direction relative to distance between position estimates.

We selected a rate coefficient (Ratecoef) of 20 for assessing the angle created by 3 consecutive points. As Ratecoef increases, the filter becomes more conservative, and relatively large distances between triplets will require a larger angle to pass the filter because a small angle would appear as a typical Argos error (i.e. the farther an animal moves, the less likely it is to return to a spot very close to the previous position). The filter eliminated points that resulted in a movement rate $>9 \mathrm{~km} \mathrm{~h}^{-1}$, which is at the upper extreme of visually observed horizontal movement rates for sperm whales noted by Whitehead (2003).

\section{Horizontal movements}

Cumulative horizontal movement was the straightline distance $(\mathrm{km})$ calculated from the day of tag deployment to the last position estimate when transmissions ceased, using all position estimates that passed the filter. Rates of horizontal movement were calculated using the straight-line distance $(\mathrm{km})$ between the consecutive 'best' daily position esti- mates (position with the highest 'location class' and therefore most accurate estimate) by the exact elapsed time (h) between those position estimates. Estimated daily distance travelled $\left(\mathrm{km} \mathrm{d}^{-1}\right)$ was determined by multiplying the rate of horizontal movement $\left(\mathrm{km} \mathrm{h}^{-1}\right)$ by $24 \mathrm{~h} \mathrm{~d}^{-1}$.

\section{Habitat}

Ocean habitat categories were defined using a bathymetric map to obtain the water depth for the daily position estimates for the sperm whales tagged in this study. Each position estimate was then assigned to 1 of 3 ocean habitats: the continental shelf, slope, or ocean basin. The bathymetry data, used for obtaining the water depths of position estimates, were extracted by overlaying point location data on a bathymetric raster surface in ArcGIS Ver. 9.2 (ESRI 2006). The bathymetric dataset used was GEBCO_08 Grid, Vers. 20091120 (www.gebco.net), with a grid resolution of 30-arc seconds. Depth values (m) were transferred to point locations using the 'intersect point tool' in Hawth's analysis tools (Beyer 2004).

Habitat categories were defined using the frequency distribution of the depth readings from a rectangular area of the GEBCO_08 Grid that included all the sperm whale position estimates from 2007 and 2009 between $10^{\circ}$ and $60^{\circ} \mathrm{N}$, and $75^{\circ}$ and $145^{\circ} \mathrm{W}$.

Ocean habitat was categorized using the following depths:

(1) Continental shelf: 0 (sea level) $-245 \mathrm{~m}$

(2) Slope: $246-2455 \mathrm{~m}$

(3) Ocean basin: 2456-9621 m

The continental shelf encompasses depths from a shallow flat area along the coast; the slope is an area where the ocean floor rapidly drops over a relatively short distance, and the ocean basin is separated from the slope by an increase in depth across the midocean.

\section{RESULTS}

\section{Satellite tags}

In summer 2007 and 2009, 6 and 5 sperm whales, respectively, were tagged offshore of Sitka, AK, in the GOA (Table 1). Nine of the 10 whales were photo-identified by the distinctive shape of their flukes and dorsal fins and were compared to the SEASWAP sperm whale catalog of identification 
photographs. Seven whales had been seen previously near fishing vessels in the eastern GOA. One whale, GOA47, was tagged in both 2007 and 2009, and identified as SWsat3 in 2007 and as SWsat7 in 2009.

The highest quality position estimates for each whale for each day resulted in 86 and 209 daily locations in 2007 and 2009, respectively. In 2007, the duration of signal contact from the satellite tags ranged from 3 to $34 \mathrm{~d}$ (median $=22 \mathrm{~d}$ ), and in 2009, signal contact ranged from 7 to $158 \mathrm{~d}$ (median $=45 \mathrm{~d}$ ) (Table 1).

\section{Horizontal movements}

The tagged sperm whales travelled to the central and northern GOA (Figs. 1 \& 2) and south to waters off Mexico (Fig. 3). Eight whales did not leave the
GOA while the tags were transmitting. Four whales (3 in 2007; 1 in 2009) stayed in the eastern GOA (Fig. 1). Three whales (2 in 2007; 1 in 2009) lingered for about a week near the tagging site and then moved north along the slope of the continental shelf edge to the central and northern GOA (Fig. 2). Two of these whales, SWsat2 and SWsat5, travelled north along the slope following the NOAA longline survey vessel, F/V Ocean Prowler. SWsat9 followed a similar movement pattern. SWsat6, tagged in 2007, travelled a little past the south end of Haida Gwaii (Queen Charlotte Islands) in northern British Columbia. This area is known for the presence of sperm whales (John Ford, Department of Fisheries and Oceans Canada [DFO] pers. comm.). Photographs of 3 sperm whales were found in both the SEASWAP catalog and the catalog of British Columbia sperm whales maintained by the DFO. SWsat6, after visiting Can-
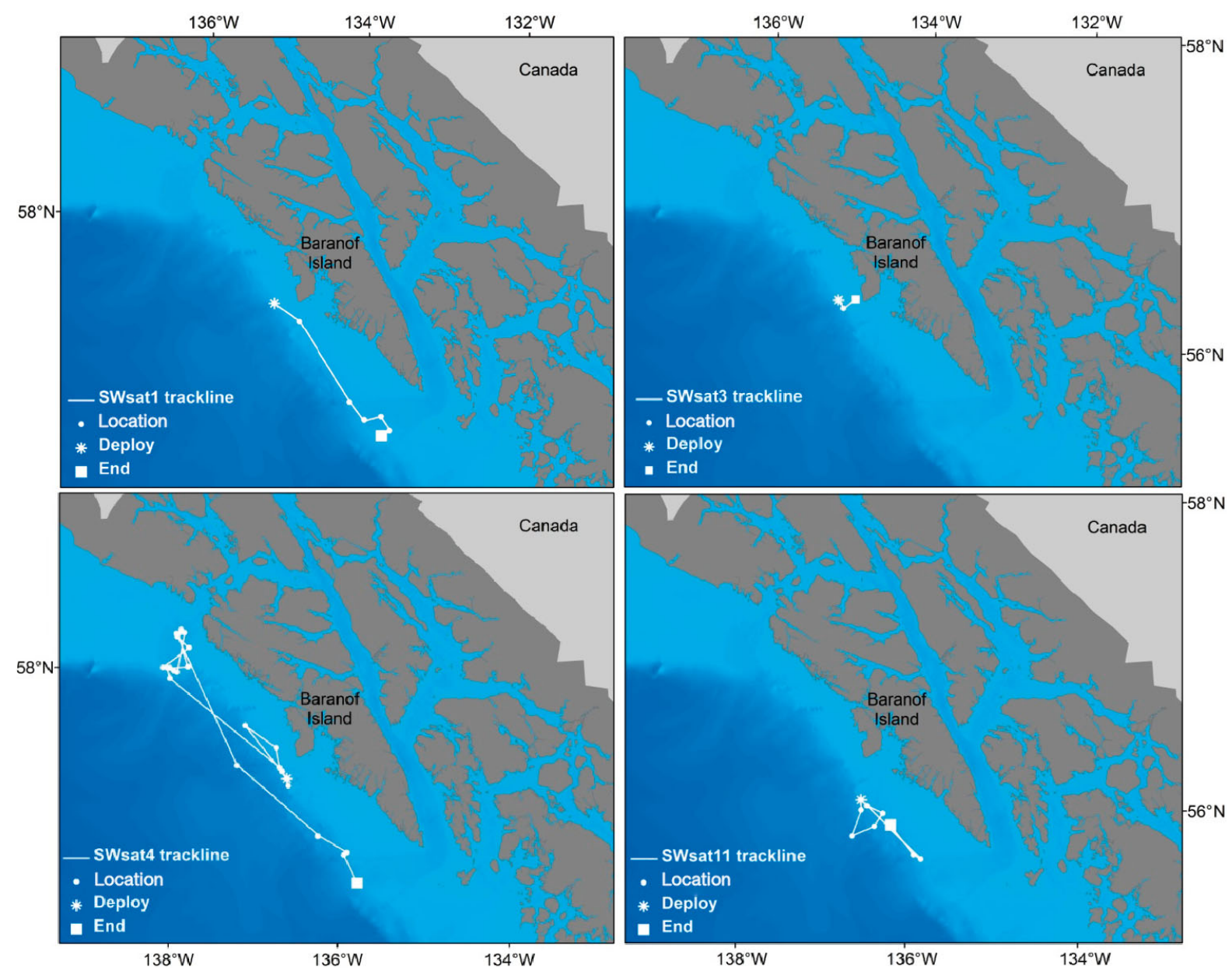

Fig. 1. Locations of 4 sperm whales Physeter macrocephalus tagged in the eastern Gulf of Alaska in 2007 and 2009. SWsat1, 3,4 , and 11 (tag durations: 9, 3, 26, and $7 \mathrm{~d}$, respectively) did not venture far from where they were tagged along the slope edge of the continental shelf. Light blue depicts the oceanic shelf, and dark blue represents the oceanic basin, with the continental slope the transition from light to dark blue. Locations connected by lines represent a trackline inferred from 2 paired transmissions, not the actual path of the whales. One degree of latitude is equivalent to 60 nautical miles 

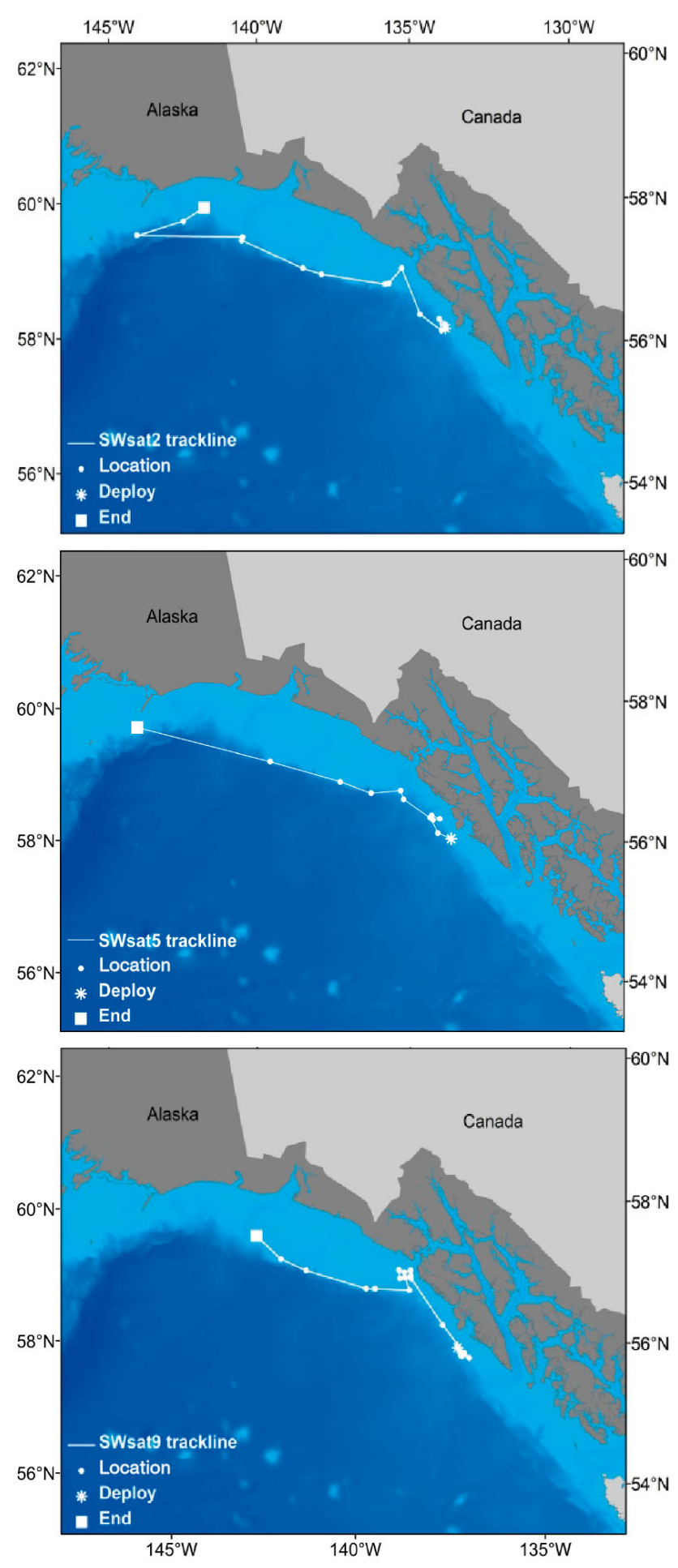

Fig. 2. Locations of 4 sperm whales Physeter macrocephalus satellite tagged in the eastern Gulf of Alaska (GOA) in 2007 and 2009. SWsat2, 5, and 9 (tag durations: 34, 18, and $16 \mathrm{~d}$, respectively) travelled to the central GOA. SWsat6 travelled into northern British Columbia, Canada, and returned north, almost returning to the eastern GOA. Bathymetry colors and locations are as in Fig. 1. One degree of latitude is equivalent to 60 nautical miles

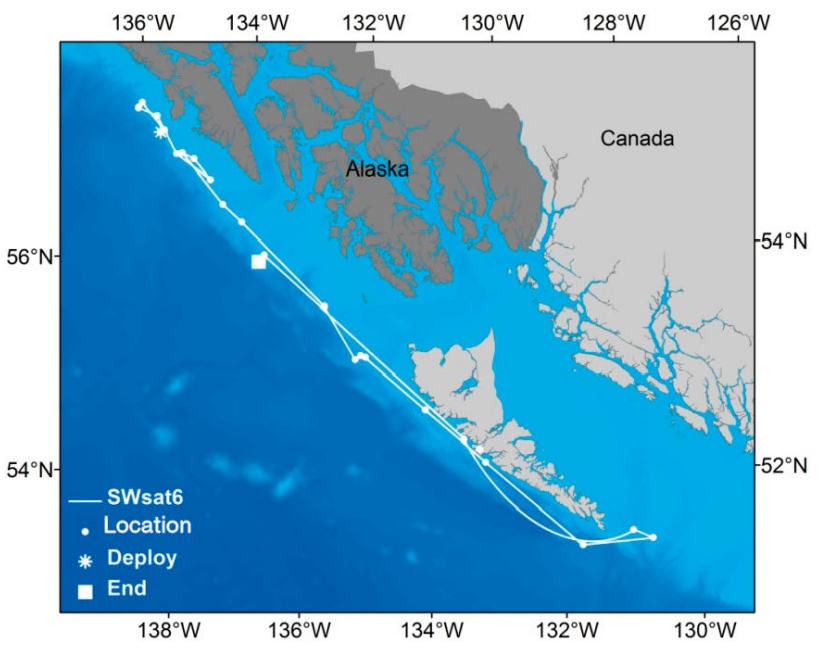

ada, returned north, and was about $80 \mathrm{~km}$ east of Noyes Island (83 km south of Sitka) when transmissions stopped (Fig. 2).

In 2009, 3 whales (SWsat7, 8, and 10) departed the GOA and headed south during the time the tags transmitted (Fig. 3). SWsat8 and SWsat10 headed south shortly after being tagged in June. SWsat8 headed south on June 13, the day it was tagged. SWsat10 headed south starting on June 18, 4 d after tagging. SWsat7 stayed in the eastern GOA until October and then headed south. SWsat8 covered a minimum cumulative distance of $5790 \mathrm{~km}$ before it reached a point offshore of southern Mexico, $5441 \mathrm{~km}$ south of the tagging site. SWsat10 also travelled south before rounding the Baja California Peninsula and travelling north, reaching the upper third of the Sea of Cortez before transmissions ceased. SWsat7 spent nearly 4 mo in the area, where he was tagged travelling along the slope, before heading south on October 8th 2009. SWsat7 reached offshore of the middle of the Baja Peninsula (a $3594 \mathrm{~km}$ great-circle distance from the tagging site) when transmissions stopped.

Overall, for all 10 whales, the median of the median rate of horizontal movement was 1.3 (range: 0.6-5.4) $\mathrm{km} \mathrm{h}^{-1}$. However, there was a difference in the median rates of horizontal movement between the whales in the GOA north and south of approximately $56^{\circ} \mathrm{N}$ (Table 2), when the satellite transmissions indicated the whale was moving in a linear path from north to south. The median of the median rate of horizontal movement for the 7 whales in the GOA north of $56^{\circ} \mathrm{N}$ was 1.3 (range: $0.6-2.5$ ) $\mathrm{km} \mathrm{h}^{-1}$, substantially slower than the median of the median rate of horizontal movement rate of 5.4 (range: $4.1-5.5$ ) $\mathrm{km} \mathrm{h}^{-1}$ for the 3 whales that departed the GOA and travelled south of $56^{\circ} \mathrm{N}$. 

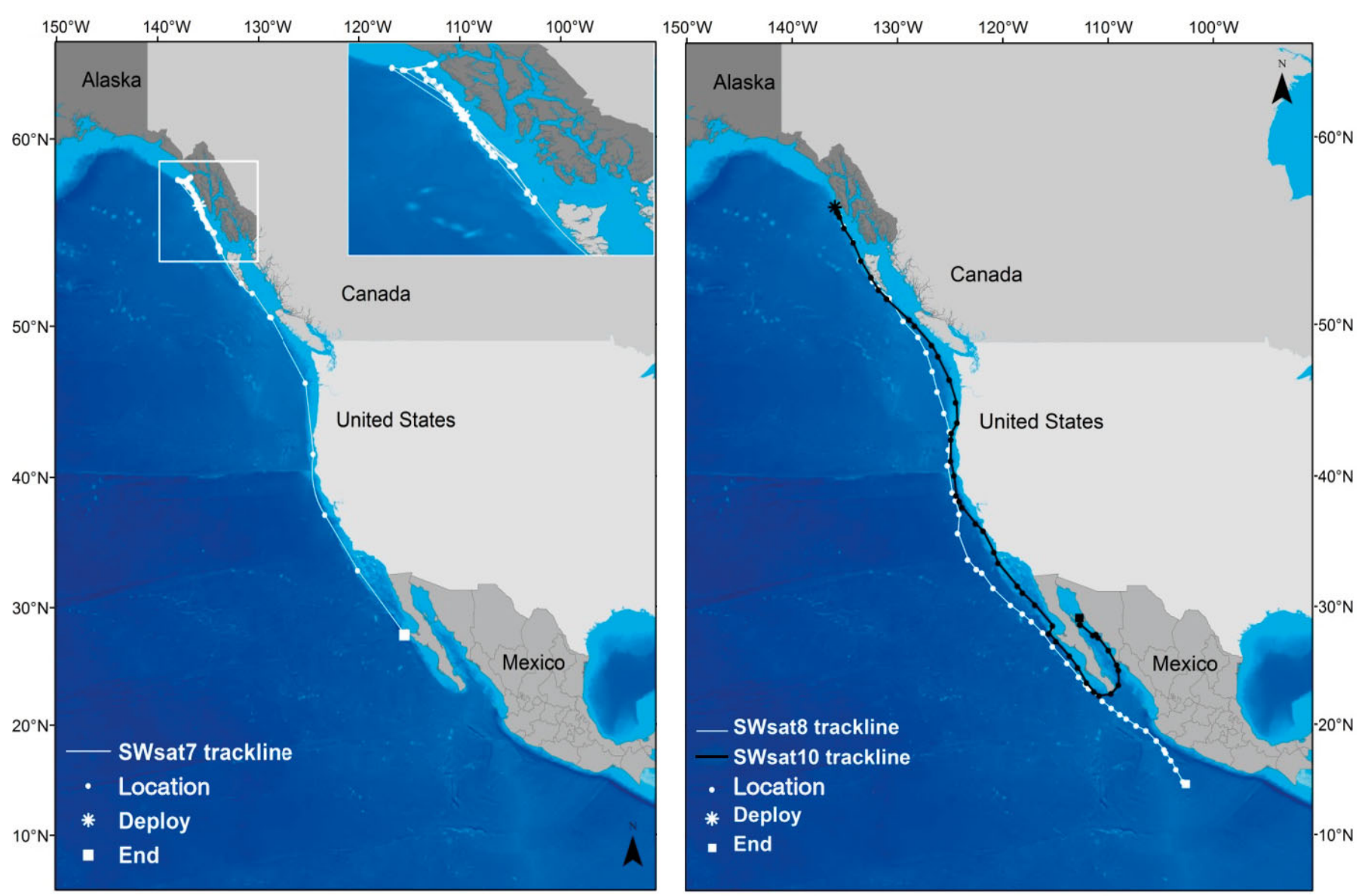

Fig. 3. Locations of 3 sperm whales Physeter macrocephalus tagged in the eastern Gulf of Alaska (GOA) in 2007 and 2009. SWsat7 (left panel) was tagged off Sitka in June 2009 and remained in the GOA until October 8 when he headed south (tag duration: $158 \mathrm{~d}$ ). Zoomed area for SWSat7 corresponds with the boxed area showing the whale locations prior to October 8. SWsat8 and SWsat10 (right panel) headed south almost immediately after tagging, with the last transmissions from Mexican waters (tag durations: 48 and $52 \mathrm{~d}$, respectively). All 3 whales veered closer to the California coastline near $40^{\circ} \mathrm{N}$ during their southbound transit. Bathymetry colors and locations are as in Fig. 1. One degree of latitude is equivalent to 60 nautical miles

Two of these whales that headed south, SWsat7 and SWsat10, came closer to shore and slightly decreased their daily distance around the latitude of $40^{\circ} \mathrm{N}$ off the coast of California, and then resumed a higher travel rate as they continued southbound (Fig. 3). SWsat8 also changed its behavior at $40^{\circ} \mathrm{N}$ by coming closer to shore so that it was transmitting over the slope instead of over the ocean basin (Fig. 3). When SWSat8 and SWSat10 reached latitudes below $30^{\circ} \mathrm{N}$ both whales decreased their horizontal movement rate; this occurred near the time their tags ceased to transmit.

\section{Habitat}

In $2007,76 \%$ of whale position estimates were from the slope, and $23 \%$ from the continental shelf.
None of the position estimates were over the ocean basin (Figs. 1-3).

In 2009,75 to $100 \%$ of position estimates for 4 of the 5 tagged whales were over the slope. Notably, for the fifth whale, SWsat $8,77 \%$ of position estimates were from over the ocean basin, and $23 \%$ from the slope.

\section{DISCUSSION}

The satellite tracking data provided details on sperm whale movement patterns, which showed considerable variation, even though whales stayed primarily along the slope. The 7 whales that stayed within the GOA moved north, south, or stayed close to where they were tagged along the slope. Some whales roamed widely along the slope, as evidenced 
Table 2. Movement details from estimated positions for 10 sperm whales Physeter macrocephalus tagged 11 times in the eastern Gulf of Alaska (GOA) in July 2007 and June 2009. Cumulative movement was the straight-line distance (km) travelled from the day of tag deployment to the last position estimate when transmissions ceased, using all filtered locations (n). Rates of horizontal movement $\left(\mathrm{km} \mathrm{h}^{-1}\right.$, range in parentheses) were calculated from consecutive pairs of the best daily locations. Estimated travel distances per day (range in parentheses) were calculated by multiplying rate of movement $\left(\mathrm{km} \mathrm{h}^{-1}\right) \mathrm{by} 24 \mathrm{~h}$. Rates of horizontal movements were calculated separately for the 3 whales with location transmissions (n) north and south of $56^{\circ} \mathrm{N}$. No data (nd) exists for the other whales not travelling $\mathrm{S}$ of $56^{\circ} \mathrm{N}$

\begin{tabular}{|c|c|c|c|c|c|c|}
\hline Whale & $\begin{array}{l}\text { Total no. } \\
\text { of locations } \\
\text { (n) }\end{array}$ & $\begin{array}{c}\text { Cumulative } \\
\text { movement } \\
(\mathrm{km})\end{array}$ & \multicolumn{2}{|c|}{$\begin{array}{l}\text { Median rate of } \\
\text { horizontal movement }\left(\mathrm{km} \mathrm{h}^{-1}\right)\end{array}$} & $\begin{array}{c}\text { Median distance } \\
\text { travelled } \\
\left(\mathrm{km} \mathrm{d}^{-1}\right)\end{array}$ & $\begin{array}{c}\text { Average } \pm \mathrm{SD} \\
\text { location } \\
\text { depth }(\mathrm{m})\end{array}$ \\
\hline \multicolumn{7}{|l|}{2007} \\
\hline SWsat1 & 6 & 146.7 & $0.7(0.1-3.2)$ & nd & $17.7(2.3-77.6)$ & $381 \pm 210$ \\
\hline SWsat2 & 14 & 804.7 & $2.1(0.4-7.9)$ & nd & $42.9(9.5-106.8)$ & $920 \pm 638$ \\
\hline SWsat $3^{b}$ & 2 & 19.2 & a & nd & a & a \\
\hline SWsat4 & 24 & 608.2 & $0.6(0.1-4.3)$ & nd & $14.2(1.5-102.1)$ & $570 \pm 370$ \\
\hline SWsat5 & 11 & 654.2 & $1.6(0.3-8.2)$ & nd & $30.0(7.5-90.1)$ & $1032 \pm 617$ \\
\hline SWsat6 & 23 & 1431.8 & $2.3(0.2-5.4)$ & nd & $56.9(4.2-128.4)$ & $443 \pm 445$ \\
\hline \multicolumn{7}{|l|}{2009} \\
\hline SWsat $7^{\mathrm{b}}$ & 78 & 6811.9 & $\begin{array}{c}1.0(0.0-4.6) \\
\mathrm{n}=67\end{array}$ & $\begin{array}{c}4.1(0.8-5.9) \\
\mathrm{n}=11\end{array}$ & $26.5(1.0-140.5)$ & $716 \pm 50$ \\
\hline SWsat8 & 46 & 5790.0 & $\begin{array}{c}2.5 \text { (no range) } \\
n=1\end{array}$ & $\begin{array}{c}5.5(3.5-6.9) \\
\mathrm{n}=45\end{array}$ & $131.1(83.3-165.1)$ & $2806 \pm 1087$ \\
\hline SWsat9 & 18 & 597.9 & $1.3(0.1-4.9)$ & nd & $30.3(3.1-116.8)$ & $518 \pm 363$ \\
\hline SWsat10 & 51 & 5559.2 & $\begin{array}{l}0.9(0.0-1.5) \\
\mathrm{n}=5\end{array}$ & $\begin{array}{c}5.4(0.4-6.8) \\
\mathrm{n}=46\end{array}$ & $122.6(0.4-163.0)$ & $1312 \pm 943$ \\
\hline SWsat11 & 8 & 164.2 & $1.3(0.3-3.1)$ & nd & $30.3(7.0-46.8)$ & $859 \pm 497$ \\
\hline
\end{tabular}

by 2 individuals that closely followed the federal longline survey vessel northbound along the slope and another whale that visited a known feeding area for sperm whales in British Columbia and then returned to Alaska.

The overall median rates of horizontal movement (range: 0.6-5.4 $\mathrm{km} \mathrm{h}^{-1}$ ) are within ranges observed for sperm whales (Whitehead et al. 1992, Jochens et al. 2008). However, the rates and behaviors were clearly different north and south of $56^{\circ} \mathrm{N}$. Although, the exact behaviors, whether foraging or travelling, will be difficult to determine because the whales were unobserved during most of the transmissions, we can infer behaviors from other sources. In the GOA, using bioacoustics suction cup tags, Mathias et al. (2012) documented foraging as a dominant behavior. Also, Whitehead et al. (2008) hypothesized $4 \mathrm{~km} \mathrm{~h}^{-1}$ to be the maximum rate of horizontal movement where maximum net energy gain is achieved during foraging. Essentially, a whale would experience a net energy gain if foraging below speeds of $4 \mathrm{~km} \mathrm{~h}^{-1}$, and, above this speed, foraging would not be beneficial. The median of median rates of horizontal movement for the whales that stayed in the GOA was below this rate, indicating foraging as a possible behavior. Along the Canadian and US West coasts south of $56^{\circ} \mathrm{N}$, the southbound whales were following a more linear path; thus, the whales were presumably travelling. Coupled with the median rate of horizontal movement that exceeded the rate of maximum net energy gain during foraging hypothesized by Whitehead et al. (2008), foraging is a less likely behavior than travelling for these southbound whales.

Interestingly, the 3 whales that travelled to Mexico ventured closer to shore, and 2 reduced their movement rates near $40^{\circ} \mathrm{N}$ latitude compared with the rest of their southward travel. At $40^{\circ} \mathrm{N}$, near the Mendicino Ridge, very deep water occurs close to the California coastline, including the Gorda Escarpment, a deep submarine canyon with complex bathymetry. This area is a biological hotspot, in particular, for reproduction of deep-water fishes and cephalopods (Drazen et al. 2003). In addition, the nearshore area between $30^{\circ}$ to $40^{\circ} \mathrm{N}$ is one of the regions of the highest marine predator density within the California Current Large Marine Ecosystem (Block et al. 2011). Although the Block et al. (2011) data were primarily for species that feed much shallower than sperm 
whales, this highly productive area supports an extensive and predictable forage base of species, including squid, for larger predators. In 2009, Humboldt squid Dosidicus gigas, a known sperm whale prey, were extremely abundant in the Northern California Current (Litz et al. 2011), just north of $40^{\circ} \mathrm{N}$, and market squid Doryteuthis opalescens were caught in record numbers throughout the California Current (Sweetnam 2010). At this latitude, the bathymetry and productivity along the California coast could provide a reliable foraging area for travelling sperm whales. However, the whales in our study, while they did slow down, did not slow to the rate hypothesized by Whitehead et al. (2008) to be the maximum rate of horizontal movement for efficient foraging $\left(4 \mathrm{~km} \mathrm{~h}^{-1}\right)$. While these 3 whales were possibly not foraging, it is noteworthy that all 3 altered their travel, at different times at the same latitude.

Despite the variability in the timing of the southbound departure from Alaskan waters and variation in movements within the GOA, none of the whales entered the mid-central GOA over the deep ocean basin, where sperm whales have been detected with autonomous hydrophone moorings (Mellinger et al. 2004) and from whaling data. If sperm whales are present in the central GOA on a regular basis, they may comprise a different population than whales observed during the present study.

The GOA sperm whales as individuals are clearly following different trajectories, as evidenced from the travel behavior of SWsat8 and SWsat10 (Fig. 3). SWsat10 headed into the Sea of Cortez, and SWsat8 bypassed the left turn to the Sea of Cortez and continued south to $14^{\circ} \mathrm{N}$ where transmissions ended. A genetics study by Mesnick et al. (2011) investigated the population structure of North Pacific sperm whales and determined that GOA males likely are from multiple origins. That study included 30 GOA biopsy samples, of which 19 were from the SEASWAP study, all males, known to have engaged in depredation. While the results of the genetic analysis did not exclude the possibility that some GOA sperm whales originated from populations off the California Current or Hawaii, none of the satellite-tagged whales made either of these areas their final destination. This could be due to the relatively short tracking duration in our study. Clearly, not all of the sperm whales in our study were headed to the same place. The one commonality for all the tagged whales was their presence along the slope, at the edge of the continental shelf, associating with vessels and removing fish from longline fishing gear while in the GOA.
The horizontal movements of male sperm whales in the GOA appear to follow the behaviors proposed by Whitehead (2003) in that male movements consist of periodic, but not seasonal, transits between the lower latitude feeding/breeding grounds and higher latitude feeding grounds. In our study, males are typically solitary, appearing to independently associate with fishing vessels along the slope, with a variable schedule for departing the higher latitude feeding areas.

Although these ocean nomads are driven by the search for food in a patchy mesopelagic habitat, there may be more to the associations among these male sperm whales than just independent whales randomly foraging in the GOA. We do not know the ages of the GOA sperm whales, but most whales included in the SEASWAP catalog are large mature males. The males appear to have no seasonal pattern to their travel between higher and lower latitudes, although our sample size is small and limited in temporal coverage. At higher latitudes in the GOA, some individuals stayed in the same general area, while others were more nomadic. GOA047 was tagged twice near the same location, and other whales were resighted in the same location across years, indicating a fidelity to either a location or perhaps association and cultural connection to other whales.

Communication among these solitary males may be a means for sperm whales to associate in higher latitudes. Communication among the solitary males may occur through low-frequency, highly resonant, vocalizations called clangs or slow clicks (Gordon 1987, Madsen et al. 2002), which differ from the usual clicks and creaks by having a slower repetition rate (inter-click interval: 5 to $8 \mathrm{~s}$ ). Clangs or slow clicks travel long distances due to their low frequency, and have been suggested to function as a long-range communication tool for males (Madsen et al. 2002, Oliveira et al. 2013, Wild 2013). Coupling satellite tracking with acoustics could provide a mechanism to understand how these whales move and travel across large ocean basins. Sperm whales moving along the slope of the GOA are typically alone and rarely in pairs or travelling or diving in synchrony with another whale. While these whales may appear solitary, they could be connecting with each other acoustically, moving in a loosely connected group, and communicating long distances while spatially separated. Skilled depredators may be functioning as scouts by showing or leading other whales to foraging hotspots, as some fishermen have speculated. 
Describing the movement patterns of sperm whales temporally and spatially in the GOA may provide a means for fishermen to avoid whales. If whales have long-term associations and if their presence can be predicted in the GOA, documenting areas and timing of frequent use by sperm whales - in particular the skilled depredators - would provide a means to minimize interactions between fishing operations and sperm whales. It is evident from our results that some whales do use the same areas over time. Fishermen could avoid fishing when certain whales are predicted to be present, thereby reducing the opportunity for depredation in Alaskan waters.

Acknowledgements. The authors thank Jennifer Cedarleaf, Lauren Wild, Delphine Mathias, Nellie Warner, Kendall Folkert and the crew of the F/V Cobra, and the crews of the F/V Ocean Prowler and Alaskan Leader for their assistance, and Sarah Mesnick for sharing results of ongoing genetic studies. Funding was provided by North Pacific Research Board, NOAA Fisheries TSMRI Auke Bay Lab sablefish assessment program, and NOAA grants to the Alaska Fisheries Science Center and Alaska Sea Life Center. Katy Echave created the wonderful maps of the locations of sperm whales. Hal Whitehead provided a thoughtful review of the manuscript and added details on what is known about the social structure of males. Three reviewers provided insightful comments. Improvements to the tagging methods were funded by Office of Naval Research Grant N000140811203. Activities were authorized under NOAA MMPA Scientific Research Permits 473-1700-01 and 02 and University of Alaska IACUC 08-07 permit issued to J. Straley.

\section{LITERATURE CITED}

Allen BM, Angliss RP (2013) Alaska marine mammal stock assessments, 2012. NOAA Tech Memo NMFS-AFSC245, US Dept of Commerce, Washington, DC, p 151-155

Andrews RD, Pitman RL, Balance LT (2008) Satellite tracking reveals distinct movement patterns for Type $\mathrm{B}$ and Type C killer whales in the southern Ross Sea, Antarctica. Polar Biol 31:1461-1468

Ashford JR, Rubilar PS, Martin AR (1996) Interactions between cetaceans and longline fishery operations around South Georgia. Mar Mamm Sci 12:452-457

Berzin A, Yablokov A (1971) Kashalot (The sperm whale). Translated from Russian [by Hoz E, Blake Z] Israel Program for Scientific Translations, Jerusalem (available from the US Dept. of Commerce, National Technical Information Service, Springfield, VA)

Best PB (1979) Social organization in sperm whales, Physeter macrocephalus. In: Winn HE, Olla BL (eds) Behavior of marine animals, Vol 3. Plenum Press, New York, NY, p 227-289

Beyer H (2004) Hawth's analysis tools for ArcGIS. Available at www.spatialecology.com/htools

Block BA, Jonsen ID, Jorgensen SJ, Winship AJ and others (2011) Tracking apex marine predator movements in a dynamic ocean. Nature 475:86-90
Capdeville D (1997) Interaction of marine mammals with the longline fishery around the Kerguelen Islands (Division 58.5.1) during the 1995/96 cruise. CCAMLR Sci 4: 171-174

Clarke MR, Macleod N (1976) Cephalopod remains from sperm whales caught off Iceland. J Mar Biol Assoc UK 56:733-750

> Douglas DC, Weinzierl R, Davidson SC, Kays R, Wikelski M, Bohrer G (2012) Moderating Argos location errors in animal tracking data. Methods Ecol Evol 3:999-1007

Drazen JC, Goffredi SK, Schlining B, Stakes DS (2003) Aggregations of egg-brooding deep-sea fish and cephalopods on the Gorda Escarpment: a reproductive hot spot. Biol Bull 205:1-7

Dufault S, Whitehead H, Dillon M (1999) An examination of the current knowledge on the stock structure of sperm whales (Physeter macrocephalus) worldwide. J Cetacean Res Manag 1:1-10

ESRI (Environmental Systems Research Institute) (2006) ESRI ArcGIS 9.1. ESRI, Redlands, CA

Gaskin DE (1982) The ecology of whales and dolphins. Heinemann, Exeter

Gordon JCD (1987) The behaviour and ecology of sperm whales off Sri Lanka. PhD thesis, University of Cambridge

Gosho ME, Rice DW, Breiwick JM (1984) The sperm whale, Physeter macrocephalus. Mar Fish Rev 46:54-64

Hanselman DH, Lunsford CR, Rodgveller C (2011) Assessment of the sablefish stock in Alaska. In: Stock assessment and fishery evaluation report for the groundfish resources of the GOA and BS/AI as projected for 2011. North Pacific Fishery Management Council, Anchorage, AK, p 307-412

Hill PS, Laake JL, Mitchell EM (1999) Results of a pilot program to document interactions between sperm whales and longline vessels in Alaska waters. NOAA Tech Memo NMFS-AFSC-108

Ivashchenko YV, Clapham PJ, Brownell RL Jr (2011) Soviet illegal whaling: the devil and the details. Mar Fish Rev 73:1-19

Ivashchenko YV, Clapham PJ, Brownell RL Jr (2013) Soviet catches of whales in the North Pacific: revised totals. J Cetacean Res Manag 13:59-71

Jochens A, Biggs D, Benoit-Bird K, Engelhaupt D and others (2008) Sperm whale seismic study in the Gulf of Mexico: synthesis report. OCS Study MMS 2008-006, US Dept of the Interior, Minerals Management Service, Gulf of Mexico OCS Region, New Orleans, LA

Kawakami T (1980) A review of sperm whale food. Sci Rep Whales Res Inst 32:199-218

Litz M, Phillips J, Brodeur R, Emmett R (2011) Seasonal occurrences of Humboldt squid (Dosidicus gigas) in the northern California current system. Calif Coop Ocean Fish Invest Rep 52:97-108

Lyrholm T, Leimar O, Johanneson B, Gyllensten U (1999) Sex-biased dispersal in sperm whales: contrasting mitochondrial and nuclear genetic structure of global populations. Proc Biol Sci 266:347-354

Madsen PT, Wahlberg M, Møhl B (2002) Male sperm whale (Physeter macrocephalus) acoustics in a high-latitude habitat: implications for echolocation and communication. Behav Ecol Sociobiol 53:31-41

Mathias D, Thode A, Straley J, Calambokidis J, Schorr G, Folkert K (2012) Acoustic and diving behavior of sperm whales (Physeter macrocephalus) during natural and 
depredation foraging in the Gulf of Alaska. J Acoust Soc Am 132:518-532

Mellinger DK, Stafford KM, Fox CG (2004) Seasonal occurrence of sperm whale sounds in the Gulf of Alaska, 1999-2001. Mar Mamm Sci 20:48-62

Mesnick SL, Taylor BL, Archer FI, Martien KK and others (2011) Sperm whale population structure in the eastern and central North Pacific inferred by the use of single nucleotide polymorphisms, microsatellites and mitochondrial DNA. Mol Ecol Resour 11(Suppl 1):278-298

Mizroch SM, Rice DW (2013) Ocean nomads: distribution and movements of sperm whales in the North Pacific shown by whaling data and Discovery marks. Mar Mamm Sci 29:E136-E165

> Nolan CP, Liddle GM (2000) Interactions between killer whales (Orcinus orca) and sperm whales (Physeter macrocephalus) with a longline fishing vessel. Mar Mamm Sci 16:658-664

Okutani T, Nemoto T (1964) Squids as the food of sperm whales in the Bering Sea and Alaska Gulf. Sci Rep Whales Res Inst 18:111-122

> Oliveira C, Wahlberg M, Johnson M, Miller PJO, Madsen PT (2013) The function of male sperm whale slow clicks in a high latitude habitat: communication, echolocation, or prey debilitation? J Acoust Soc Am 133:3135-3144

Rendell L, Mesnick SL, Dalebout ML, Burtenshaw J, Whitehead H (2012) Can genetic differences explain vocal dialect variation in sperm whales, Physeter macrocephalus? Behav Genet 42:332-343

Rice DW (1989) Sperm whale (Physeter macrocephalus). In: Ridgway SH, Harrison R (eds) Handbook of marine mammals, Vol 4. Academic Press, London, p 177-233

Santos MB, Pierce GJ, Boyle PR, Reid RJ and others (1999)

Editorial responsibility: Sascha Hooker, St. Andrews, UK
Stomach contents of sperm whales Physeter macrocephalus stranded in the North Sea 1990-1996. Mar Ecol Prog Ser 183:281-294

Sigler MF, Lunsford CR, Straley JM, Liddle JB (2007) Sperm whale depredation of sablefish longline gear in the northeast Pacific Ocean. Mar Mamm Sci 24:16-27

Straley J, O'Connell V, Behnken L, Mesnick S, Liddle J (2005) Sperm whale and longline fisheries interactions in the Gulf of Alaska. North Pacific Research Board Final Report R0309, North Pacific Research Board, Anchorage, AK

Sweetnam D (2010) Review of selected California fisheries for 2009: coastal pelagic finfish, market squid, red abalone, dungeness crab, Pacific herring, groundfish/ nearshore live-fish, highly migratory species, kelp, California halibut, and sandbasses. Calif Coop Ocean Fish Invest Rep 51:14-38

Thode A, Straley J, Tiemann C, Teloni V, Folkert K, O'Connell T, Behnken L (2007) Evaluation of sperm whale deterrents. North Pacific Research Board Final Report F0527, Anchorage, AK

Whitehead H (2003) Sperm whales: social evolution in the ocean. University of Chicago Press, Chicago, IL

Whitehead H, Brennan S, Grover D (1992) Distribution and behaviour of male sperm whales on the Scotian Shelf, Canada. Can J Zool 70:912-918

> Whitehead H, Coakes A, Jaquet N, Lusseau S (2008) Movements of sperm whales in the tropical Pacific. Mar Ecol Prog Ser 361:291-300

Wild L (2013) Clangs up high: sperm whale (Physeter macrocephalus) slow clicks in the Gulf of Alaska. Master of Research thesis, Marine Mammal Science, University of St. Andrews

Submitted: September 23, 2013; Accepted: February 25, 2014 Proofs received from author(s): April 6, 2014 